\title{
IMPLEMENTASI KURIKULUM 2013 DI SEKOLAH DASAR STUDI TENTANG BEST PRACTICE YANG DILAKUKAN \\ GURU SEKOLAH DASAR DALAM PERENCANAAN, PELAKSANAAN, DAN PENILAIAN KURIKULUM 2013
}

\section{Rusman}

Program Studi Pengembangan Kurikulum SPs UPI

Email: rusman@upi.edu

\begin{abstract}
ABSTRAK
Penerapan kurikulum baru, yaitu implementasi Kurikulum 2013 di sekolah telah dimulai sejak bulan Juli 2013. Implementasi Kurikulum tersebut diharapkan mendorong peningkatan kualitas manajemen dan proses pendidikan pada setiap satuan pendidikan yang mengarah pada upaya peningkatan mutu pendidikan. Dilatarbelakangi oleh adanya penerapan kurikulum 2013 yang berorientasi pada pencapaian kompetensi abad-21 dan pendidikan karakter dalam rangka menyongsong revolusi industri 4.0 tersebut, penelitian ini bertujuan untuk mengetahui respon guru terhadap implementasi kurikulum 2013 dan "best practice" implementasi kurikulum 2013. Metode penelitian ini menggunakan metode survei dengan instrumen kuesioner dan daftar isian untuk menyampaikan pengalaman. Analisis data menggunakan statistik deskripsi-prosentase dan deskriptif-kualitatif. Hasil penelitian menunjukkan bahwa Respon guru SD terhadap terhadap implementasi Kurikulum 2013 di Kota Bandung berada pada kategori positif. Untuk kegiatan perencanaan berada pada kategori sangat positif, sedangkan untuk kegiatan pelaksanaan dan penilaian kurikulum berada pada kategori positif. Terdapat beberapa "best practice" yang dapat dicontoh dalam perencanaan, pelaksanaan, dan penilaian dari guru SD di Kota Bandung terkait dengan implementasi Kurikulum 2013 berupa kegiatan "sharing", "hearing", "in house training", dan "modelling real teaching" yang dilaksanakan di $\mathrm{KKG}$ atau KKG gugus.
\end{abstract}




\title{
Kata Kunci: Kurikulum 2013, Respon Guru dan Best practice Implementasi Kurikulum.
}

\begin{abstract}
The implementation of the new curriculum, namely the implementation of the 2013 Curriculum in schools began in July 2013. The implementation of the curriculum is expected to encourage improvement in the quality of management and the education process in each education unit that leads to efforts to improve curriculum quality. education quality. With the background of the implementation of the 2013 curriculum oriented to the achievement of 21st century competency and character education in order to fulfill the industrial revolution 4.0, this study aims to determine the teacher's response to the implementation of the 2013 curriculum and the implementation of the 2013 curriculum best practice. survey with questionnaire and questionnaire instruments to convey experience. Data analysis uses statistical and qualitative-descriptive descriptions. The results showed that the response of elementary school teachers to the implementation of the 2013 curriculum in the city of Bandung was in the positive category. Planning activities are in a very positive category, while for curriculum implementation and assessment activities are in the positive category. There are several "best practices" that can be replicated in planning, implementing, and evaluating elementary school teachers in Bandung City related to the implementation of the 2013 curriculum in the form of "sharing" activities, "hearing", "in house training ", and "modeling real teaching" applied at the KKG or KKG cluster.
\end{abstract}

Keywords: 2013 curriculum, teacher response and curriculum implementation best practices.

\section{A. PENDAHULUAN}

Ditetapkannya Peraturan Pemerintah Nomor 32 Tahun 2013 tentang Perubahan Atas Peraturan Pemerintah Nomor 19 Tahun 2005 tentang Standar Nasional Pendidikan dan Permendikbud No. 81A tentang Implementasi Kurikulum diharapkan mendorong peningkatan kualitas pengelolaan pendidikan pada satuan pendidikan yang 
mengarah pada upaya peningkatan mutu pendidikan, khususnya melalui penerapan kurikulum baru, yakni implementasi Kurikulum 2013 di sekolah dan madrasah yang telah dimulai sejak bulan Juli 2013. Terdapat beberapa faktor yang dapat menjadi penyebab sukses tidaknya implementasi kurikulum. Dilihat dari dimensi kurikulum, Hasan menjelaskan bahwa implementasi kurikulum adalah dimensi proses. Hasan memaparkan bahwa: ${ }^{1}$

“... Dimensi proses adalah implementasi dari apa yang direncanakan dalam dimensi dokumen. Pelaksanaan atau implementasi itu mungkin sama tapi mungkin juga berbeda dari apa yang direncanakan dalam dokumen"

Dari paparan tersebut dapat diambil suatu pengertian bahwa implementasi kurikulum (dimensi proses, disebut dengan istilah implemented, observed, atau reality) terkait erat dengan dokumen kurikulum tertulis atau written document (dimensi dokumen).

Senada dengan pendapat tersebut, Ornstein \& Hunkins menyatakan bahwa "successful curriculum implementation results from careful planning, which focuses on three factors: people, programs, and process". ${ }^{2}$ Lebih lanjut mereka menjelaskan bahwa beberapa sekolah telah gagal mengimplementasikan kurikulum karena mengabaikan faktor orang dan mencurahkan banyak waktu dan dana hanya untuk memodifikasi program atau prosesnya saja. Di sisi lain memfokuskan pada program baru memberikan cara baru kepada orang untuk mencapai program baru pada sekolah. Proses pengorganisasian juga penting, karena dapat menggerakkan orang untuk memandu kepada hal yang diperlukan untuk kesuksesan implementasi.

Pada implementasi KTSP yang diberlakukan sejak tahun 2006, permasalahan yang muncul pada pengembangan kurikulum adalah ketidaksiapan tim pengembang kurikulum sekolah dan daerah untuk mengembangkan kurikulum sesuai dengan potensi dan karakteristik yang dimiliki sekolah dan daerah. Hal ini disebabkan oleh rendahnya kompetensi tim pengembang kurikulum dalam mengembangkan kurikulum. Rendahnya kompetensi tersebut disebabkan oleh tidak optimalnya kegiatan peningkatan kompetensi dalam bentuk pelatihan dan bimbingan teknis yang dibekalkan kepada tim pengembang kurikulum sekolah.

1. S. H. Hasan, Pengembangan Kurikulum Sekolah Dalam Ilmu Dan Aplikasi Pendidikan (Bandung: Pedagogiana, 2007), hlm. 479.

2. A.C. Ornstein and F.P. Hunkins, Curriculum, Foundations, Principles, and Issues. Fifth Ed (Singapore: Pearson, 2009), hlm. 250. 
Hasil penelitian yang dilakukan pengusul di enam Kabupaten/ Kota di Jawa Barat menunjukkan bahwa pengalaman keikutsertaan guru dalam pelatihan atau bimbingan teknis (diklat/ bimtek) sebagai tim pengembangan kurikulum secara umum berada pada kategori memadai dengan persentase sebanyak $42 \%$ dan kurang memadai sebanyak 45\%. Lebih lanjut dijelaskan bahwa dari data hasil penelitian diperoleh informasi sebanyak $45 \%$ guru sebagai tim pengembang kurikulum belum pernah mengikuti diklat/ bimtek yang terkait dengan pengembangan KTSP, silabus, dan RPP. ${ }^{3}$ Temuan tersebut sejalan dengan hasil penelitian yang menunjukkan bahwa secara umum gambaran kualitas kurikulum SD di enam daerah Provinsi Jawa Barat yang berada pada kategori tidak baik sebanyak $2 \%$, kurang baik sebanyak $50 \%$ dan kategori baik $48 \%{ }^{4}$

Berdasarkan temuan tersebut, untuk meningkatkan kompetensi tim pengembang kurikulum di sekolah dan daerah dan sekaligus dalam upaya meningkatkan kualitas dokumen KTSP yang disusun oleh tim pengembang kurikulum diperlukan upaya yang lebih serius dan intens. Salah satu upaya tersebut dapat dilakukan dengan memberikan pelatihan disertai dengan pendampingan selama proses pengembangan dan penyusunan kurikulum itu dilakukan.

Hasil studi pendahuluan yang dilakukan peneliti juga menunjukkan kondisi yang tidak jauh berbeda. Masih ada sekolah yang tidak memiliki tim pengembang kurikulum dan belum memiliki KTSP. Tidak sedikit sekolah yang menyatakan telah memiliki KTSP hanya dengan cara mengadopsi KTSP yang telah disusun oleh sekolah dan pihak lain. KTSP yang seharusnya melahirkan keberagaman, tetapi berujung pada keseragaman. Adanya realitas seperti ini, tentunya disebabkan oleh berbagai faktor, antara lain oleh ketidaksiapan tim pengembang kurikulum di sekolah, khususnya diduga karena belum memadainya kompetensi yang dimiliki tim pengembang kurikulum sekolah untuk mengembangkan KTSP dan perangkat pendukung lainnya.

Keberhasilan implementasi kurikulum menurut Ornstein \& Hunkins dipengaruhi oleh tiga faktor, yaitu: orang, program, dan proses. Terkait dengan faktor orang, di Indonesia, guru menjadi faktor yang sangat strategis dalam pengembangan dan

3. Susilana R., The Implementation of Diversified Curriculum in Elementary Schools (A Study on the Contribution of Self-Efficacy of Curriculum Development Team and Document Quality to the Implementation of Diversified Curriculum in West Java). Dissertation (Bandung: FPS UPI, 2013), hlm. 156.

4. Ibid., hlm. 168 . 
pelaksanaan kurikulum di sekolah. Tercapai tidaknya tujuan pendidikan lebih banyak dipengaruhi oleh kemampuan guru, misalnya terkait dengan kompetensi profesional yang dimiliki, motivasi kerja, kinerja yang tampilkan, dedikasi, keyakinan akan kemampuan diri, dan pengalaman guru, baik latar belakang kualifikasi akademik, keikutsertaan dalam diklat profesional, maupun lama mengajar. Selain oleh faktor guru, implementasi kurikulum juga diduga berkaitan dengan faktor program, dalam penelitian ini program diasumsikan sebagai dokumen kurikulum yang disusun tim pengembang kurikulum. ${ }^{5}$ Kualitas dokumen kurikulum yang baik semestinya dapat menjadi pedoman bagi pelaksana kurikulum (guru) untuk dapat mengimplementasikan kurikulum dengan baik pula.

Merujuk pada paparan di atas, dalam penelitian ini dirumuskan permasalahan penelitian sebagai berikut: Bagaimanakah respon guru SD terhadap terhadap implementasi Kurikulum 2013 di Kota Bandung dilihat dari kegiatan perencanaan, pelaksanaan, dan penilaian kurikulum? dan "Best Practice" apa yang dapat dicontoh dari guru SD di Kota Bandung terkait dengan implementasi Kurikulum 2013 dalam perencanaan, pelaksananan, dan penilaian?

Berdasarkan rumusan masalah tersebut, penelitian ini ditujukan untuk memperoleh gambaran tentang implementasi Kurikulum 2013, khususnya terkait dengan "best practice" yang dapat dicontoh dalam hal perencanaan, pelaksanaan, dan penilaian kurikulum yang dilakukan oleh guru SD di Kota Bandung. Penelitian ini juga diharapkan dapat memberikan manfaat yang praktis akan memberikan acuan/ pedoman bagi para guru dan sekolah yang mau menerapkan kurikulum 2013, khususnya rujukan bagi para guru dan sekolah yang mau dan akan menerapkan kurikulum 2013.

\section{B. KAJIAN TEORI}

Dalam Oxford Advance Learner Dictionary dikemukakan bahwa "implementation" (implementasi) adalah "put something into effect" (penerapan sesuatu yang memberikan efek atau dampak). Terkait dengan pengertian implementasi dalam bidang kurikulum, Miller \& Seller (1985) mendefinisikan kata implementasi dengan tiga pendekatan, yaitu: a) implementasi didefinisikan sebagai kegiatan; b) implementasi sebagai suatu usaha meningkatkan proses interaksi antara pengembang

5. A.C. Ornstein and F.P. Hunkins, Curriculum, Foundations, Principles, and Issues. Fifth Ed, hlm. 250. 
guru dengan guru; dan c) implementasi merupakan sesuatu yang terpisah dari komponen kurikulum. ${ }^{6}$

Hal yang senada dijelaskan oleh Saylor dan Alexander (1974) dalam Miller and Seller bahwa implementasi kurikulum sebagai proses menerapkan rencana kurikulum (program) dalam bentuk pembelajaran, melibatkan interaksi siswa-guru dan dalam konteks persekolahan. ${ }^{7}$ Demikian pula dinyatakan oleh Fullan \& Pomfret dalam Marsh bahwa istilah "implementasi" menunjuk pada "penggunaan nyata (actual use)" dari kurikulum/ silabus, atau hal-hal apa saja yang ada dalam praktik. ${ }^{8}$ Senada dengan Fullan \& Pomfret, Hasan menyatakan bahwa implementasi kurikulum adalah "usaha merealisasikan ide, konsep, dan nilai-nilai yang terkandung dalam kurikulum tertulis menjadi kenyataan". 9

Selanjutnya,Marshmemaparkanbahwakurikulumdiawalisebagaisebuahrencana. Kurikulum hanya akan menjadi kenyataan bila para guru mengimplementasikannya pada siswa dan kelas yang sesungguhnya. Perencanaan dan pengembangan yang cermat sangatlah penting, namun hal tersebut tidak akan bermakna apa pun jika para guru tidak memiliki kesadaran akan produk dan tidak memiliki keterampilan untuk mengimplementasikan kurikulum di kelas mereka. ${ }^{10}$ Sebagaimana dinyatakan oleh Fullan dan Scott dalam Marsh (1999), sebuah kurikulum, bagaimana pun bagusnya dirancang, haruslah diimplementasikan jika diinginkan memiliki dampak pada siswa. Terdapat ribuan dokumen kurikulum yang disimpan di rak karena tidak pernah diimplementasikan atau karena tidak diimplementasikan dengan cerdas. Pentingnya implementasi kurikulum tidak serta merta membawa pada meluasnya pemahaman tentang apa yang dituntut dari kurikulum dan permasalahan apa saja yang berkenaan dengan kurikulum.

Pinar dan Irwin menyatakan bahwa implementasi kurikulum dapat dipahami dari dua hal, yaitu: implementasi kurikulum sebagai tindakan instrumental dan implementasi kurikulum sebagai praktik situasional (curriculum implementation as instrumental action and as situational praxis). ${ }^{11}$

6. J.P. Miller and Seller Wayne, Curriculum; Perspective and Practice (London: Longman, 1985).

7. Ibid., hlm. 246.

8. C. J. Marsh, Key Concepts for Understanding Curriculum, 3rd Edition (Oxon: RoutledgeFalmer, 2004), hlm. 65.

9. S. Hamid Hasan, Evaluasi Kurikulum (Jakarta: P2LPTK, 1988), hlm. 11.

10. C. J. Marsh, Key Concepts for Understanding Curriculum, 3rd Edition, hlm. 65-75.

11. W.F. Pinar and R.L. Irwin, Curriculum in a New Key: The Collected Works of Ted T. Aoki (NJ: Lawrence Erlbaum Associates, 2005), hlm. 118-120. 
Pertama, implementasi kurikulum sebagai tindakan instrumental. Implementasi program dapat ditemukan dalam paradigma produsen-konsumen dengan kata lain bahwa paradigma ini memandang implementasi dalam alur satu arah di mana ahli menghasilkan sesuatu untuk non-ahli yang menjadi konsumennya. Ahli kurikulum menghasilkan program (kurikulum) bagi konsumen, yaitu guru dan siswa. Pengimplementasian kurikulum dalam paradigma ini menimbulkan masalah mendasar yang terkait dengan bagaimana komunikasi dapat dilakukan secara efektif dengan orang-orang yang tidak memiliki keterlibatan, baik dalam menetapkan tujuan, maupun dalam merancang sumber daya, strategi belajar mengajar, dan rencana evaluasi. Oleh karena itu masalah implementasi seringkali dipandang dalam term keefektifan komunikasi. Dalam perspektif ini, seorang guru implementator yang kompeten adalah seseorang yang memiliki keterampilan dan teknik yang berorientasi pada kendali yang efisien. Pandangan "know how to do" dalam implementasi ini melekat dalam kerangka kerja pemikiran/ tindakan ilmiah dan teknologis yang mengurangi kompetensi manusia terhadap alasan instrumental dan tindakan instrumental. Di sini, guru dilihat sebagai yang berorientasi pada aturan (rule-oriented), atau dikuasai aturan.

Kedua, implementasi kurikulum sebagai praktik situasional. Pandangan lain tentang implementasi didasarkan pada pengalaman manusia dalam situasi kelas. Ini merupakan dunia pengalaman guru dengan para siswanya. Jika akan menginterpretasikan implementasi kurikulum sebagai praktik (praxis), maka harus mengetahui asumsi yang membedakannya dengan asumsi yang mendasari implementasi sebagai instrumental, sebagai berikut.

Asumsi 1: humanisasi merupakan vokasi manusia yang mendasar (basic human vocation). Dalam pandangan ini, guru yang diminta untuk mengimplementasikan kurikulum X harus dipandang tidak dalam makna sebagai "sesuatu" (being-as-thing) namun sebagai manusia yang memiliki minat untuk menjadi sesuatu yang sesuai dengan yang dirinya dan orang lain harapkan. Sedangkan pandangan instrumental dari implementasi "mentekniskan" (technisizing) guru, menutupi subjektivitasnya.

Asumsi 2: manusia memiliki kemampuan untuk merubah realitanya (dalam hal ini, merubah dirinya dan kurikulum X). Dalam pandangan ini, guru dipandang sebagai "orang yang bertindak" (a person-who-acts) dan juga sebagai pencipta dari realitanya sendiri. Dengan demikian, ia menginterpretasikan berdasarkan wawasannya mengenai kurikulum $\mathrm{X}$ dan terlibat secara situasional dalam perubahan ini. 
Asumsi 3: pendidikan tidak pernah netral. Dalam asumsi ini, implementasi kurikulum merupakan sebuah tindakan politis. Dalam konteks hubungan sosial, aktivitas implementasi merupakan masalah kekuasaan dan kendali (kontrol).

Kurikulum 2013 adalah kurikulum berbasis kompetensi. Kurikulum berbasis kompetensi adalah "outcomes-based curriculum" dan oleh karena itu pengembangan kurikulum diarahkan pada pencapaian kompetensi yang dirumuskan dari SKL. Demikian pula penilaian hasil belajar dan hasil kurikulum diukur dari pencapaian kompetensi. Keberhasilan kurikulum diartikan sebagai pencapaian kompetensi yang dirancang dalam dokumen kurikulum oleh seluruh peserta didik.

Kompetensi dalam Kurikulum 2013 dirancang sebagai berikut: (a) Isi atau konten kurikulum yaitu kompetensi dinyatakan dalam bentuk Kompetensi Inti (KI) kelas dan dirinci lebih lanjut dalam Kompetensi Dasar (KD) mata pelajaran; (b) Kompetensi Inti (KI) merupakan gambaran secara kategorial mengenai kompetensi dalam aspek sikap, pengetahuan, dan ketrampilan (kognitif dan psikomotor) yang harus dipelajari siswa sekolah dasar, kelas dan mata pelajaran. Kompetensi Inti adalah kualitas yang harus dimiliki seorang siswa untuk setiap kelas melalui pembelajaran KD yang diorganisasikan dalam proses pembelajaran tematik terpadu; (c) Kompetensi Dasar (KD) merupakan kompetensi yang dipelajari siswa pada suatu tema-tema yang telah ditetapkan; (d) Kompetensi Inti dan Kompetensi Dasar di SD diutamakan pada ranah sikap dan kognitif (kemampuan kognitif tinggi-HOTS); (e) Kompetensi Inti menjadi unsur organisatoris (organizing elements) Kompetensi Dasar yaitu semua KD dan proses pembelajaran dikembangkan untuk mencapai kompetensi dalam Kompetensi Inti; (f) Kompetensi Dasar yang dikembangkan didasarkan pada prinsip akumulatif, saling memperkuat (reinforced) dan memperkaya (enriched) antar mata pelajaran dan jenjang pendidikan (organisasi horizontal dan vertikal); (g) Silabus di SD dikembangkan sebagai rancangan belajar untuk satu tema. Dalam silabus tercantum seluruh KD untuk tema di kelas tersebut; (h) RPP dikembangkan dari Silabus untuk setiap tema yang berisi muatan beberapa mata pelajaran. ${ }^{12}$ (Rusman, 2013)

\section{METODE PENELITIAN}

Penelitian ini dilaksanakan di Kota Bandung dengan sasaran guru-guru SD yang berjumlah 25 orang. SD yang dipilih adalah SD yang menjadi sekolah sasaran

12. Rusman, Manajemen Kurikulum (Jakarta: Raja Grafindo Indonesia, 2013). 
implementasi Kurikulum 2013 sebanyak 10 sekolah. Metode yang digunakan dalam penelitian ini adalah metode survei dengan instrumen kuesioner dan daftar isian untuk menyampaikan pengalaman. Analisis data menggunakan statistik deskripsiprosentase dan deskriptif-kualitatif.

\section{HASIL PENELITIAN}

Ada dua hal yang disajikan sebagai hasil penelitian, yaitu respon guru terhadap implementasi Kurikulum 2013 dan "best practice" implemnetasi Kurikulum 2013.

\section{Respon Guru}

Respon guru SD terhadap implementasi Kurikulum 2013 di Kota Bandung pada tiga kegiatan (perencanaan, pelaksanaan dan penilaian) terdapat pada kategori positif. Respon guru positif pada implementasi kurikulum 2013. Tetapi masih ada guru yang belum mengimplementasikan kurikulum 2013 pada tiga kegiatan, yaitu sebanyak $16 \%$, walaupun semua responden penelitian ini adalah guru yang sudah mengikuti pelatihan kurikulum 2013. Hal ini juga terjadi pada guru SD di Yayasan Kanisius cabang Jawa Tengah dan Yogyakarta yang sesuai dengan dengan hasil penelitian dari Krissandi dan Rusmawan jurnal Cakrawala Pendidikan bahwa kendala yang dialami guru SD dalam implementasi kurikulum 2013 meliputi pembuatan media pembelajaran, pemahaman guru, pemaduan antar muatan pelajaran dalam pembelajaran tematik, dan penguasaan teknologi informasi. ${ }^{13}$ Sementara itu, penelitian studi dokumen dari Astiningtyas dalam jurnal Primary Program Studi Pendidikan Guru Sekolah Dasar diperoleh hasil bahwa kesiapan guru dalam mengaplikasikan kurikulum 2013 memiliki rata-rata sebanyak $17,3 \% .^{14}$

Artinya masih ada guru yang belum memahami dan belum mampu melaksanakan implementasi Kurikulum 2013. Hal ini dapat ditindaklanjuti oleh kepala sekolah, atau pihak dinas pendidikan terkait sosialisasi dan penguatan implementasi kurikulum 2013 pada pembelajaran di sekolah. Terdapat 20\%

13. Apri Damai Sagita Krissandi and Rusmawan, "Kendala Guru Sekolah Dasar Dalam Implementasi Kurikulum 2013," Jurnal Cakrawala Pendidikan Tahun XXXIV, No. 3 (Oktober 2015), hlm. 456-461.

14. Anna Astiningtyas, "Kesiapan Guru Sekolah Dasar Dalam Pelaksanaan Pembelajaran Tematik Integratif Pada Kurikulum 2013," Jurnal Primari Program Studi Pendidikan Guru Sekolah Dasar Fakultas Keguruan Dan Ilmu Pendidikan Universitas Riau Volume 7 Nomor 1 (April 2018): hlm. 64-65. 
guru yang merespon negatif terhadap pelaksanaan pembelajaran dan penilaian pembelajaran. Hal ini dapat dijelaskan karena pelaksanaan pembelajaran Kurikulum 2013 menekankan pada pendekatan tematik dan saintifik dan penilaian pembelajaran Kurikulum 2013 menekankan penilaian otentik. Kedua hal ini masih dianggap baru dan kemungkinan belum dipahami dengan baik oleh guru yang merespon negatif tersebut. Sedangkan untuk perencanaan pembelajaran pada Kurikulum 2013 dianggap oleh para guru tidak terlalu banyak berbeda dengan perencanaan pembelajaran pada kurikulum sebelumnya sehingga pada umumnya guru memberi respon sangat positif.

\section{Best Practice}

Informasi yang disampaikan guru melalui format isian tentang "best practice" dalam kegiatan pada implementasi Kurikulum 2013 dapat dipaparkan sebagai berikut.

\section{"Best Practice" dalam Kegiatan Perencanaan Pembelajaran.}

Dalam kegiatan perencanaan pembelajaran guru berkewajiban untuk membuat RPP. Untuk memudahkan dalam mengembangkan RPP, guru-guru SD di Kota Bandung melaksanakannya secara bersama-sama dalam KKG dan atau kelompok KKG dalam satu gugus. RPP dibuat dengan mengacu pada buku guru dan buku siswa yang diberikan oleh Pemerintah, tetapi dikembangkan dengan tambahan materi, kegiatan dan metode. Kegiatan KKG di sebagian sekolah ini dilakukan tiap satu minggu sekali dengan pembahasan: 1 . membaca silabus yang akan dituangkan pada RPP; 2. pembuatan RPP dilaksanakan sehari sebelum pelaksanaan kegiatan pembelajaran; 3. penyediaan alat/ bahan/ media disesuaikan dengan kondisi linngkungan yang ada di sekitar sekolah kami; dan 4. menganalisis buku guru dan buku siswa untuk mengatur pelaksanaan pembelajarab bila ada hal yang kurang.

Di sebagian sekolah yang ada di Kota Bandung, misalnya di SDPN Sabang, setiap awal tahun pelajaran guru menyelenggarakan "In House Training" dengan menghadirkan nara sumber yang berkompeten dalam bidang Kurikulum 2013 dan mengundang orang tua murid untuk mensosialisasikan kurikulum 2013 kepada orang tua murid agar mau memahami dan mau bekerja sama dalam menerapkan kurikulum 2013. Setiap hari kamis mengadakan kegiatan KKG yang diikuti oleh seluruh guru kelas dan guru bidang studi untuk membahas perangkat kurikulum 2013, diantaranya pembuatan kisi-kisi soal penilaian tengah semester 
(PTS), pembuatan soal PTS, dan penilaian Kurikulum 2013. Selain itu diadakan pertemuan kegiatan KKG antar gugus atau kecamatan untuk membahas kendalakendala yang berkaitan dengan implementasi Kurikulum 2013. Di sekolah tersebut juga, kepala sekolah mewajibkan setiap guru kelas dan guru bidang studi untuk mengumpulkan RPP yang dibuatnya selama satu minggu setiap hari senin.

Guru SD di Kota Bandung juga merancang kegiatan alternatif yang disiapkan jika terjadi hal-hal yang di luar RPP yang tel;ah dirancang. Kegiatan alternatif tersebut, diantaranya: 1. menyiapkan gambar yang berkaitan dengan materi untuk diwarnai oleh anak.; 2. menyiapkan kuis yang berhubungan dengan materi pelajaran; 3. mengajak peserta didik menyanyikan lagu-lagu; dan 4. menyiapkan permainan sambung kata sehingga tanpa disadari anak-anak belajar tentang kosa kata sebanyak-banyaknya.

Untuk memudahkan memonitor pencapaian KI.1 dan KI.2, pihak sekolah di Kota Bandung ada yang memfasilitasinya dengan menggunakan stempel atau good point berupa stiker bintang yang diberikan langsung saat siswa bisa menunjukkan indikator sikap dengan baik untuk menilai sikap spiritual (untuk muatan mapel agama dan budi pekerti) dan sikap sosial (untuk muatan maple PPKn). Hal ini digunakan guru untuk monitoring sikap siswa per harinya berdasarkan indikator sikap yang telah dirumuskan di akhir minggu. Map stempel ini dipinjam kepada siswa untuk dibawa pulang dan dikroscek oleh orang tua sehingga terjalin komunikasi tentang perkembangan sikap putra-putrinya.

Terkait dengan kemampuan membaca pada anak-anak kelas rendah, guru SD di Kota Bandung memfasilitasinya dengan kegiatan "klinik kelas" menyediakan waktu khusus untuk membaca permulaan bagi yang belum lancar membaca. Latihannya dilaksanakan sebelum masuk sekolah atau setelah pulang sekolah.

Kegiatan lain yang biasa dilakukan oleh guru-guru SD di Kota Bandung dalam melaksanakan kurikulum 2013 adalah: (1) Berdiskusi sebelum dan sesudah mengajar untuk membicara temuan di lapangan dan kendala yang dialami ketika mengajar; (2) Observasi oleh teman sejawat; (3) Menambahkan materi/ bahan pelajaran yang relevan dengan cara mencari dari internet, koran atau majalah.

\section{"Best practice" dalam Kegiatan Pelaksanaan Pembelajaran.}

Ada beberapa "best practice" yang dilakukan oleh guru-guru SD di Kota Bandung dalam pelaksanaan pembelajaran. Diantaranya sebagai berikut: untuk mempermudah dan menarik minat siswa dalam kegiatan menanya, menalar, dan 
mencoba digunakan media nyata (lingkungan setempat), metode yang bervariasi, dan pengaturan kelas. Pembagian kelompok dilakukan bergantian/ diputar dalam waktu seminggu sekali dengan memperhatikan tingkat intelegensi siswa. Mengawali pembelajaran dengan membaca surat-surat pendek Al-quran dan doa harian. Sebelum memulai pembelajaran juga ditanamkan nilai-nilai karakter yang baik bisa berupa nyanyian, kata-kata inspiratif baik dari siswa maupun dari guru untuk memotivasi siswa agar dapat berperilaku positif dan lebih bersemangat dalam pembelajaran. misalnya: salam KOCAK: Kreatif, Optimis, Cerdas, Antusias, Komunikatif. Melengkapi pembelajaran dengan media yang menarik misalnya menanyakan video yang berkaitan dengan materi yang diajarkan sehingga siswa lebih memahami yang dipelajarinya. Hal ini terjadi di VI SDPN Sabang di mana semua kelas empat paralel (IV A, IV B, IV C, IV D, IV E) dipasang infocus.

Buku sumber yang digunakan tidak terpaku pada buku Pemerintah, tetapi ada buku pendamping yang lain, 1-2 buku dan dalam setiap pembelajaran diupayakan memakai media audio visual.; (1) Menggunakan LCD untuk mengamati; (2) Penggunaan bintang untuk penilaian sikap; (3) Penggunaan stamp (good job and excellent) untuk motivasi siswa; (4) Banyak memberi pengalaman belajar dengan cara praktik; serta melakukan real teaching satu gugus, di mana rekan-rekan guru akan menilai/ memberi masukan atas pembelajaran yang sudah dilakukan guru model.

\section{"Best practice" dalam Kegiatan Penilaian Pembelajaran.}

Terkait dengan kegiatan penilaian pembelajaran, guru-guru SD di Kota Bandung sudah terbiasa membuat soal dan diawali dengan menyusun kisi-kisi soal, baik untuk soal penilaian harian (PH), penilaian tengah semester (PTS) dan penilaian akhir semester (PAS) yang dibuat di KKG dengan bimbingan kepala sekolah dan pengawas. Pembuatan soal dari kisi-kisi dan soal ulangan mengacu pada buku guru dan buku siswa. Guru bekerja sama dengan orang tua untuk menginformasikan tingkat kemajuan siswa dalam pembelajaran dalam periode tertentu.

Pelaksanaan penilaian KI-1, KI-2, KI-3, KI-4 dibuat persubtema. Penilaian KI-1 dilakukan pada saat siswa berdoa sebelum belajar (diamati apakah berdoa, berbicara dengan temannya), bisa diamati juga pada saat sholat Dhuha di sekolah, siswa juga ditanya apakah sudah sholat 5 waktu (Dzuhur, Asar, Magrib, Isya dan Subuh). Penilaian KI-2 dilakukan pada saat siswa mengumpulkan tugas 
apakah tepat waktu atau tidak, kedisiplinan masuk sekolah (terlambat/ tidak) dan untuk penerapan kedisiplinan, di kelas dipasang nama siswa berdasarkan urutan kehadiran siswayang datang paling awal mendapat tanda bintang. Penilaian sikap sosial juga dilakukan dengan pemilihan siswa teladan setiap bulan, kriteria siswa yang dipilih, yaitu yang disiplin, tanggung jawab, percaya diri, santun, peduli, dan bisa menjadi contoh bagi teman-temannya. Siswa teladan ini dipilih oleh siswa dikelas.

Penilaian KI-3, dilakukan untuk penilaian harian $(\mathrm{PH})$ setelah selesai satu subtema diadakan ulangan secara tertulis yang memuat PPKn, B. Indonesia, Matematika, IPA dan IPS. Bagi siswa yang belum tuntas diberikan remedial untuk tiap muatan/ kompetensi dasar yang nilai belum mencapai KKM/ Ketuntasan Belajar Minimal (KBM). Setelah selesai dinilai dan diremedial, nilai hasil ulangan dimasukan ke folder di laptop supaya memudahkan pada saat memproses nilai rapot. selain ulangan, penilaian juga bisa dilakukan dengan cara penugasan yang dikerjakan di rumah. Penilaian KI-4, dilakukan secara langsung pada saat siswa melakukan aktivitas pembelajaran maupun pada saat mengerjakan penugasan. Untuk memudahkan penulisan rapor digunakan program mailing atau aplikasi.

\section{E. SIMPULAN DAN SARAN}

Berdasarkan temuan dan analisis data dapat dirumuskan simpulan penelitian sebagai berikut.

Respon guru SD terhadap terhadap implementasi Kurikulum 2013 di Kota Bandung berada pada kategori positif. Untuk kegiatan perencanaan berada pada kategori sangat positif, sedangkan untuk kegiatan pelaksanaan dan penilaian kurikulum berada pada kategori positif.

Ada beberapa "best practice" yang dapat dicontoh dari guru SD di Kota Bandung terkait dengan implementasi Kurikulum 2013 dalam hal kegiatan perencanaan kurikulum, diantaranya bahwa guru SD di Kota Bandung secara kolaboratif mengembangkan RPP di masing-masing KKG dan KKG gugus melalui kegiatan "sharing" dan "in house training" dengan mendatangkan instruktur nasional dan atau narasumber Kurikulum 2013; mengembangkan kegiatan alternatif di luar yang telah dicanangkan dalam RPP; dan mengadakan "klinik kelas" bagi siswa kelas rendah yang belum pandai membaca. 
Ada beberapa "best practice" yang dapat dicontoh dari guru SD di Kota Bandung terkait dengan implementasi Kurikulum 2013 dalam hal kegiatan pelaksanaan kurikulum, diantaranya bahwa guru SD di Kota Bandung sudah melakukan optimalisasi sumber belajaryang ada di sekitar dalam proses pembelajaran berbarengan dengan mengoptimalkan media pembelajaran elektronik; melakukan pergantian atau perputaran pengelolaan kelas dan pengelompokkan siswa; melakukan inovasi dalam proses pembelajaran, yakni: a) menggunakan LCD untuk mengamati; b) Penggunaan "bintang" untuk penilaian sikap; c) Penggunaan stamp (good job and excellent) untuk motivasi siswa; dan d) Banyak memberi pengalaman belajar dengan cara praktik; serta e) melakukan real teaching satu gugus, di mana rekan-rekan guru akan menilai/ memberi masukan atas pembelajaran yang sudah dilakukan guru model.

Ada beberapa "best practice" yang dapat dicontoh dari guru SD di Kota Bandung terkait dengan implementasi Kurikulum 2013 dalam hal kegiatan penilaian kurikulum, diantaranya bahwa guru SD di Kota Bandung sudah melaksanakan penilaian otentik dengan berbagai cara dan dalam berbagai kegiatan; melakukan "hearing" dengan orang tua siswa dalam memantau kemajuan belajar siswa; dan menggunakan aplikasi komputer untuk mempermudah membuat laporan hasil penilaian.

Beberapa saran yang dapat disampaikan berdasarkan hasil penelitian ini sebagai berikut.

Ada tiga kegiatan utama guru dalam mengimplementasikan kurikulum, yaitu merencanakan, melaksanakan, dan melakukan penilaian. Kompetensi ketiga komponen tersebut menjadi kompetensi yang wajib dimiliki seorang guru.

Peningkatan ketiga kompetensi utama tersebut dapat dilakukan melalui berbagai cara, dari "best practice" guru-guru SD di Kota Bandung dapat diambil pelajaran bahwa kegiatan "sharing", "hearing", "in house training", dan "modelling real teaching" yang dilaksanakan di KKG atau KKG gugus merupakan kegiatan yang dapat membantu meningkatkan kompetensi guru. Oleh karena itu untuk meningkatkan kompetensinya, guru disarankan untuk mengikuti kegiatan-kegiatan tersebut, baik secara mandiri maupun secara berkelompok. Kompetensi yang tinggi diharapkan dapat meningkatkan citra diri dan kepercayaan diri untuk mencapai martabat "guru sebagai penyandang profesi yang profesional". 


\section{F. DAFTAR PUSTAKA}

A.C. Ornstein, and F.P. Hunkins. Curriculum, Foundations, Principles, and Issues. Fifth Ed. Singapore: Pearson, 2009.

Anna Astiningtyas. "Kesiapan Guru Sekolah Dasar Dalam Pelaksanaan Pembelajaran Tematik Integratif Pada Kurikulum 2013.” Jurnal Primari Program Studi Pendidikan Guru Sekolah Dasar Fakultas Keguruan Dan Ilmu Pendidikan Universitas Riau Volume 7 Nomor 1 (April 2018): 64-65.

Apri Damai Sagita Krissandi, and Rusmawan. "Kendala Guru Sekolah Dasar Dalam Implementasi Kurikulum 2013." Jurnal Cakrawala Pendidikan Tahun XXXIV, No. 3 (Oktober 2015): 456-61.

C. J. Marsh. Key Concepts for Understanding Curriculum, 3rd Edition. Oxon: RoutledgeFalmer, 2004.

J.P. Miller, and Seller Wayne. Curriculum; Perspective and Practice. London: Longman, 1985.

Rusman. Manajemen Kurikulum. Jakarta: Raja Grafindo Indonesia, 2013.

S. H. Hasan. Pengembangan Kurikulum Sekolah Dalam Ilmu Dan Aplikasi Pendidikan. Bandung: Pedagogiana, 2007.

S. Hamid Hasan. Evaluasi Kurikulum. Jakarta: P2LPTK, 1988.

Susilana R. The Implementation of Diversified Curriculum in Elementary Schools (A Study on the Contribution of Self-Efficacy of Curriculum Development Team and Document Quality to the Implementation of Diversified Curriculum in West Java). Dissertation. Bandung: FPS UPI, 2013.

W.F. Pinar, and R.L. Irwin. Curriculum in a New Key: The Collected Works of Ted T. Aoki. NJ: Lawrence Erlbaum Associates, 2005. 
